\title{
Determinants of Life Satisfaction for Rural North Indians: Estimation Using Generalised Ordinal Logistic Regression
}

\author{
Suraj Sharma \\ Department of Economics, S.M. (P.G.) College, Chandausi, M.J.P. Rohilkhand University, Bareilly, Uttar Pradesh, India
}

Corresponding author: surajsharma1903@gmail.com

Received: $18-09-2020$

Revised: 23-11-2020

Accepted: 06-12-2020

\begin{abstract}
The study presents the results of a survey experiment aimed at assessing the level of life satisfaction for rural north Indians and captures the determinants in deciding one's satisfaction level. The study hypothesised human, material and social capital plays a significant role in determining one's level of life satisfaction. The study uses individual data from the Sanitation Quality, Use, Access and Trends (SQUAT) survey collected in rural Bihar, Haryana, Madhya Pradesh, Rajasthan, and Uttar Pradesh in 2013-14 from India. The study estimates first, proportional odds logistic regression, followed by Generalised Ordinal Logistic regression techniques. It is evident from the analysis that the overall PO assumption, as well as separate PO assumptions for most of the variables, is violated and, in that case, generalised ordinal logistic regression may provide a better model. From the analysis, it is very clear that for rural north Indians the level of life satisfaction is most affected by health status, possession of agricultural land,and administrative environment of villages (e.g., functioning of Panchayats).
\end{abstract}

Keywords: Generalised ordinal logistic model; human capital; life satisfaction; rural India; social capital

The study of social welfare has gained interest among scholars from different disciplines over the last few years which raised the importance of satisfaction. From the classical utilitarianism to neoclassical marginal utility approach and from egalitarian utilitarianism to implicit value judgments and ethics, the concept of welfare economics has seen a drastic change over the centuries. Classical utilitarianism focused on national welfare as a whole to increase the total utility of the community and gave lesser importance to the individual utility. Even the utility functions are assumed to be linear which means utility increases at a constant rate for every individual whether he/she is most or least wealthy and where it does not matter if the welfare of the most or least wealthy is increased. Neoclassicals helped in this regard and gave the concept of diminishing marginal utility of welfare which ultimately influenced towards 'egalitarian' approach as to maximise the social welfare by increasing the welfare of the least wealthy.

Egalitarian utilitarianism emphasised not only production but also on redistribution of income but it was assumed that this redistribution would not affect society's total income. This formed the basis of new welfare economics which gave importance to 'allocative efficiency' and 'optimisation problem' but economic calculation problem related to the measurement of welfare and varying optima leads to the introduction of economic efficiency with distributive justice which

How to cite this article: Sharma, S. (2020). Determinants of Life Satisfaction for Rural North Indians: Estimation Using Generalised Ordinal Logistic Regression. Int. J. Soc. Sci., 9(04): 273-283.

Source of Support: None; Conflict of Interest: None 
introduced distributive justice to the agenda and explicit value judgments about the distribution of income. This approach gave more importance to individual choice and preference. Now the focus has been changed from total national income to individual welfare and satisfaction as Sen (1990) rightly pointed out that utility means happiness and desire fulfillment which is associated with consumption of goods \& services and amount of leisure enjoyed. It is closely related to political, economic, social, cultural, and environmental factors that provide real freedom that people enjoy.

The consumption of goods and services depends on its utility to the individual which leads to satisfaction or well-being; the aggregate of total utility for an individual, from consumption of goods and services. The economics of welfare gives importance to value decisions for maximum welfare of society; that is an aggregate of utilities or satisfaction obtained by individuals from the same society, because of the ordinal nature of utility. Scholars have earlier used terms like; 'subjective well-being' or 'happiness' for analysing the overall life satisfaction and its determinants (Alexandrova 2005; Li et al. 2012) but most empirical researches are now using the term 'life satisfaction' because it only focuses on the overall evaluation of life leaving aside the current feelings, emotions and psychological thoughts (Borg et al. 2006; Myers \& Diener 1995; Zaidi et al. 2009). The term 'life satisfaction' can also be linked to the economics of utility or the utility from one's life as a whole (Veenhoven 2015) over a period which cannot be measured exactly but one can relatively put oneself in a scale measuring overall life satisfaction.

In practice to measure life satisfaction common methods like Life Satisfaction Index (LSI) and the Satisfaction with Life Scale (SWLS) were used (Diener et al. 1985; Neugarten et al. 1961) which were mostly based on symmetric scaling of opinions or attitudes (Likert scale methods) and getting ordinal responses. This makes the measurement of life satisfaction quite difficult which gives rise to an approach of the single direct question within the context of survey schedule which includes possible outcomes on a ladder-like situation and makes it cardinal with a specific order (Dolan et al. 2008) and assumes that an individual can differentiate among every ladder and can put herself/himself on a particular ladder at a particular point of time.

Estimation of life satisfaction depends on many social, economic, cultural, political, etc. factors that have varying spatial and temporal effects. Earlier crosscountry studies (Diener and Seligman 2004; Frey and Stutzer 2002; Hayo 2004) have shown that human capital indicators like age, education, and health are strongly associated with the level of life satisfaction. Better occupational status, higher relative socioeconomic status also increases well-being and level of life satisfaction. Here particularly for rural setups, the possession of agricultural land and asset count can also be taken as proxies for socioeconomic status.

The literature on life satisfaction and its determinants are fairly available in the context of western countries and studies (Maass et al. 2016; Takahashi et al. 2011) found social capital; particularly group membership or participation in multiple groups is significantly associated with increased life satisfaction as social capital; measured by social trust, civic engagement and relations, also influence the health status of an individual (Helliwell \& Putnam 2004; Kawachi et al. 2008; World Health Organisation [WHO] 2003) thereby influencing life satisfaction. Many other studies (Anheier et al. 2004; Bjornscov 2005; Elgar et al. 2011) have also found a strong positive correlation between social capital and self-reported well-being. Angelini et al. (2017) using six specific life domains e.g. income, family, job, friends, sentiment relationships, and health found raising awareness of these life domains strongly correlated with self-reported levels of life satisfaction and effects were not homogenous across subgroups which can be also be seen in caste and class system of contemporary India. Ebrahim et al. (2013) found similar results for South Africa where race and gender differences were prevalent in deciding one's level of life satisfaction with blacks and females being the least satisfied taking other socio-economic factors as constant.

The nature and characteristics of an economy from the west are different from Asian countries but the determinants of life satisfaction are near to similar. A study (Ngoo et al. 2015) found that income is not only 
one big influencer of SWB and factors like married status, relative living standard, and role of government have a greater influence on life satisfaction in Asian countries rather only talking about age, education, and gender. So, family values, culture, and good governance are more important factors for Asian countries. Similarly comparing Europe and Asia, Jagodzinski (2010) found economic factors influencing both the regions in the same way but social and cultural factors strongly influence the level of life satisfaction when it comes to Asian countries.

Particularly in India, a study (Spears 2016) explores caste norms and differences in the level of life satisfaction which solely cannot be explained by mere economic differences measured by income, asset count, or wealth. Antaramian et al. (2015) found a significant association between coping behaviour of problem-solving/ externalizing behaviour and level of life satisfaction. Similarly, for elderly individuals, cognitive health was the most influential factor in deciding life satisfaction level and social support was also among the main factors other than socio-economic and demographic variables (Banjare et al. 2015).

\section{Objective and hypothesis}

Earlier reviews showed that there is a dearth of literature on life satisfaction when it comes to Asian countries, particularly the developing and less developed countries from Asia. I found very few studies from India and even that were only related to limited factors influencing life satisfaction. The present study tries to measure the level of life satisfaction for rural north Indians and capture the determinants in deciding one's satisfaction level. The study hypothesised that whether human, material and social capital play a significant role in determining one's level of life satisfaction and for testing the same on econometric tools the study presents the methodology and conceptual framework in subsequent sections.

\section{Data and Methodology}

The present study uses individual data from the Sanitation Quality, Use, Access and Trends (SQUAT) survey collected in rural Bihar, Haryana, Madhya Pradesh, Rajasthan, and Uttar Pradesh in 2013-14 by a team of researchers. These data and their representative sampling strategy have previously been described in detail in Coffey et al. (2014). The cleaned SQUAT dataset and questionnaires are publicly available online ${ }^{1}$. The SQUAT survey was a multipurpose survey with hourlong interviews on a range of topics. Therefore, neither the occupational nor caste-related questions could directly influence the asset count measure (Deaton and Stone 2013). The sample size of the SQUAT survey is 24,070 and all respondents pertain to rural areas. The study filtered out the individuals who rely on "pension" and "others" category of the main source of livelihood and social category classified as "others" category. Nonresponse and filtering used in the study narrowed down the sample to 17,091 in the present case.

\section{Variables}

The study uses various variables which are described by variable type, description, and corresponding range (see table 1).

Table 1: Description of variables used in the study

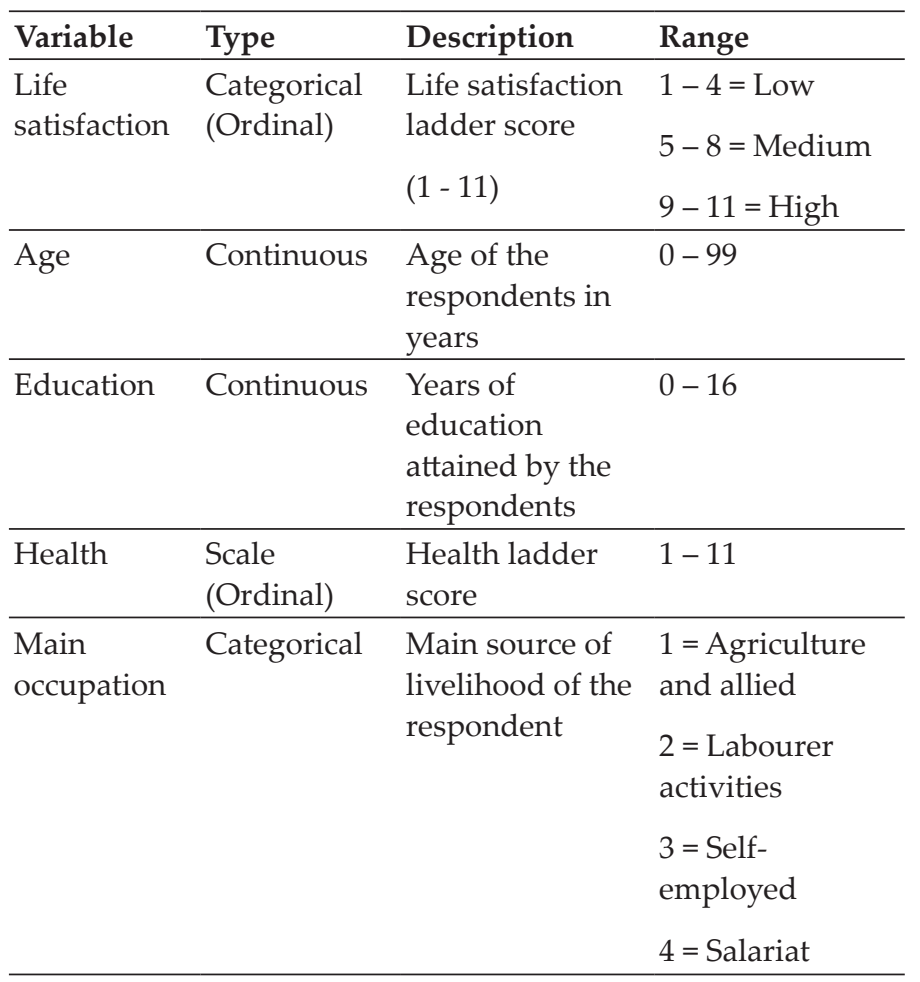

${ }^{1}$ The data set and questionnaires are available at www.riceinstitute.org 


\begin{tabular}{|c|c|c|c|}
\hline $\begin{array}{l}\text { Agricultural } \\
\text { land }\end{array}$ & Dummy & $\begin{array}{l}\text { Possession of } \\
\text { agricultural land }\end{array}$ & $\begin{array}{l}1=\text { Yes } \\
0=\text { No }\end{array}$ \\
\hline Asset count & Continuous & $\begin{array}{l}\text { Summation of } \\
\text { assets }\end{array}$ & $0-26$ \\
\hline $\begin{array}{l}\text { Social } \\
\text { category }\end{array}$ & Categorical & $\begin{array}{l}\text { Social category of } \\
\text { the respondent }\end{array}$ & $\begin{array}{l}1=\text { General } \\
2=\mathrm{OBC} \\
3=\mathrm{SC} / \mathrm{ST}\end{array}$ \\
\hline $\begin{array}{l}\text { Heterogene- } \\
\text { ity of castes }\end{array}$ & Categorical & $\begin{array}{l}\text { People in village } \\
\text { mostly of } \\
\text { similar castes or } \\
\text { different types of } \\
\text { castes. }\end{array}$ & $\begin{array}{l}1 \text { = Similar } \\
2=\text { Different }\end{array}$ \\
\hline $\begin{array}{l}\text { Peaceful } \\
\text { environment }\end{array}$ & Categorical & $\begin{array}{l}\text { Do people of } \\
\text { different castes } \\
\text { live together } \\
\text { peacefully, or is } \\
\text { there a conflict? }\end{array}$ & $\begin{array}{l}1 \text { = Conflicts } \\
2=\text { Peaceful }\end{array}$ \\
\hline $\begin{array}{l}\text { Functioning } \\
\text { of Panchayat }\end{array}$ & Categorical & $\begin{array}{l}\text { How is the } \\
\text { functioning of } \\
\text { Panchayat? }\end{array}$ & $\begin{array}{l}0=\text { Do not exist } \\
1=\text { Not good } \\
2=\text { Good }\end{array}$ \\
\hline Male & Dummy & $\begin{array}{l}\text { Gender of the } \\
\text { respondent }\end{array}$ & $\begin{array}{l}1=\text { Male } \\
0=\text { Female }\end{array}$ \\
\hline $\begin{array}{l}\text { State } \\
\text { dummies }\end{array}$ & Categorical & $\begin{array}{l}\text { State of the } \\
\text { respondent }\end{array}$ & $\begin{array}{l}1=\text { Haryana } \\
2=\text { Bihar } \\
3=\text { Uttar Pradesh } \\
4=\text { Madhya } \\
\text { Pradesh } \\
5=\text { Rajasthan }\end{array}$ \\
\hline
\end{tabular}

Source: Calculations based on SQUAT 2013.

\section{Theoretical modeling framework}

The outcome variable is the life satisfaction level of rural north Indian individuals, which is an ordinal variable with three levels ( $1=$ low life satisfaction; $2=$ medium life satisfaction and $3=$ high life satisfaction level). These three levels of satisfaction were upward ordinal structured and table 2 provides the categories and frequencies of life satisfaction ladder score.

As our dependent variable is ordinal of categories then conventional ordinary least square (OLS) regression techniques are inappropriate because OLS regression is only useful when the dependent variable is continuous. In such cases where the dependent variable is ordinal of categories of more than two, the proportional odds model or ordered logit regression is a better alternative. However, in cases, the assumption of proportional odds or parallel lines is violated; the generalised ordinal logit regression is a superior alternative because it is less restrictive than earlier methods and more parsimonious than methods like multinomial logit regression which does not consider the ordinal nature of regressand.

\section{The proportional odds ( $\mathrm{PO}$ ) model}

The PO model estimates the cumulative probability of being at or below a particular level of the dependent variable or being beyond that level. The interpretation of predictors in this model is according to the assumption of proportional odds or parallel line which assumes the effect of each predictor is to be the same across the categories of the ordinal regressand, meaning thereby, for each regressor, the effect on the likelihood of being at or below any level/category does not change within the model.

The binary logistic regression analysis, as we know, should have a dichotomous dependent variable. As far as the regressand is categorical, we cannot predict ordinary least square (OLS) estimates because the bestfit approach is based on minimizing error term and this is inappropriate in the case of categorical regressand. For that purpose, binomial probability theory is applied in logistic regression which predicts only two values: that probability ( $\mathrm{p}$ ) is 1 or 0 , i.e. the event/person belongs to one group or the other.

The logistic regression model can be defined as:

$$
\begin{aligned}
1 n\left(Y^{\prime}\right) & =\log i t[p(\underline{x})] \\
1 n\left(Y^{\prime}\right) & =\ln \left(\frac{p(\underline{x})}{1-p(\underline{x})}\right) \\
\ln \left(Y^{\prime}\right) & =\alpha+\beta_{1} X_{1}+\beta_{2} X_{2}+\beta_{3} X_{3}+\ldots+\beta_{n} X_{n}
\end{aligned}
$$

But as the study encounters regressand that is of more than two categories as well as ordinal, the ordinal logistic regression estimated the odds of being at or below a specific outcome level given some regressors. 
The aforementioned model can be expressed in the following form as follows:

$$
\begin{aligned}
& \ln \left(Y_{j}^{\prime}\right)=\log i t\left[p_{j}(\underline{x})\right] \\
& \ln \left(Y_{j}^{\prime}\right)=\ln \left(\frac{p_{j}(\underline{x})}{1-p_{j}(\underline{x})}\right) \\
& \ln \left(Y_{j}^{\prime}\right)=\alpha_{j}+\left(-\beta_{1} X_{1}-\beta_{2} X_{2}-\beta_{3} X_{3}-\ldots-\beta_{n} X_{n}\right)
\end{aligned}
$$

Where $p_{j}(\underline{x})=p\left(Y \leq j / x_{1}, x_{2^{\prime}}, x_{3^{\prime}}, \ldots, x_{n}\right)$ is the odds of being at or below level/category $j, j=1,2,3 \ldots \mathrm{J}-1, \alpha_{j}$ are cut points which usually indicates where the regressand is cut to make three categories that I observe in data. In general, the cut-points are closely related to thresholds and $\beta_{1}, \beta_{2}, \beta_{3^{\prime}} \ldots \beta_{n}$ are logit coefficients. This PO model estimates $\mathrm{J}-1$ cut points and according to PO or parallel line assumption, it assumes the coefficients for the underlying binary models are the same across all cut points.

To estimate the likelihoods of being at or below the $j^{\text {th }}$ category, the PO model can be extended as follows:

$$
\begin{aligned}
& \log i t\left[p\left(Y \leq j / x_{1}, x_{2}, x_{3}\right)\right]=1 n\left(\frac{p\left(Y \leq j / x_{1}, x_{2}, x_{3} \ldots x_{n}\right)}{p\left(Y>j / x_{1}, x_{2}, x_{3} \ldots x_{n}\right)}\right) \\
& \operatorname{logit}\left[\mathrm{p}\left(Y \leq j / x_{1}, x_{2^{\prime}}, x_{3^{\prime}}, \ldots, x_{n}\right)\right]=\alpha_{j}+\left(-\beta_{1} \mathrm{X}_{1}-\beta_{2} \mathrm{X}_{2}-\right. \\
& \left.\beta_{3} \mathrm{X}_{3}-\ldots-\beta_{n} \mathrm{X}_{n}\right)
\end{aligned}
$$

Most of the time the PO assumption is violated for some or the other regressors and I have to go for postestimation tests like the Brant test to testify whether the PO assumption is met for some or the other regressors or not. The Brant test estimates logistic coefficients for underlying binary logistic regression and produces the chi-square test statistics for each regressor and the overall model.

\section{The generalised ordinal logistic regression (GOLOGIT) model}

The GOLOGIT model is an extension or improvement over the PO model. Whenever the PO assumption is violated for some or the other predictor variables, the PO estimations are not correct or more appropriately say not correctly specified. The Brant test, which is used to testify the $\mathrm{PO}$ assumption, specifies which regressors are violating the $\mathrm{PO}$ assumption, and if the assumption is violated by certain regressors, then the GOLOGIT model estimates the odds freely across different levels/ categories of the regressand. The model can be expressed as follows:

$$
\begin{aligned}
& \ln \left(Y_{j}^{\prime}\right)=1 n\left(\frac{p_{j}(\underline{x})}{1-p_{j}(\underline{x})}\right) \\
& \ln \left(Y_{j}^{\prime}\right)=\alpha_{j}+\left(\beta_{1 j} X_{1}+\beta_{2 j} X_{2}+\beta_{3 j} X_{3}+\ldots+\beta_{n j} X_{n}\right)
\end{aligned}
$$

The above form can also be rewritten as follows:

$$
\begin{aligned}
& \log i t\left[\left(Y>j / x_{1}, x_{2}, x_{3}, \ldots, x_{n}\right)\right]=\ln \left(\frac{p\left(Y>j / x_{1}, x_{2}, x_{3}, \ldots, x_{n}\right)}{p\left(Y \leq j / x_{1}, x_{2}, x_{3}, \ldots, x_{n}\right)}\right) \\
& \quad \operatorname{logit}\left[p\left(Y>j / x_{1}, x_{2}, x_{3^{\prime}}, \ldots, x_{n}\right)\right]=\alpha_{j}+\left(\beta_{1 j} X_{1}+\beta_{2 j} X_{2}\right. \\
& \left.\quad+\beta_{3 j} X_{3}+\ldots+\beta_{n j} X_{n}\right)
\end{aligned}
$$

Where $\alpha_{j}$ are the cut points or intercepts, and $\beta_{1 j^{\prime}} \beta_{2 j^{\prime}}$ $\beta_{3 j^{\prime}}, \ldots, \beta_{n j}$ are logistic coefficients. This model estimates the likelihood of being beyond a certain level/category relative to being at or below that level/category. A positive logit coefficient indicates that the likelihood of being in a higher level/category is more for an individual/event than to a lower level/category of the regressand and vice versa. To estimate the likelihoods of being at or below a particular level/category, however, the signs must be reversed before both the intercepts and logit coefficients in equation (5).

A special case of the GOLOGIT model is the Partial Proportional Odds (PPO) model, which allows for interactions between a regressor that violates the $\mathrm{PO}$ assumption and different levels/categories of the ordinal regressand. On the other hand, the GOLOGIT model relaxes the $\mathrm{PO}$ assumption for each regressor to vary across different cut-points of the ordinal regressand i.e. this model estimates parameters that are different from the PPO model.

First, the Proportional Odds (PO) model uses the life satisfaction level as our regressand and human capital, material capital, and social capital as our regressors to estimate the level of life satisfaction among rural north Indians. The study controls for gender and state variables to capture the regional differences in life satisfaction 
levels of individuals. The human capital variables include age, years of education and health perspective of individuals, material capital includes the main source of livelihood (main occupation), possession of agricultural land and asset count and lastly; social capital includes the social category, heterogeneity of castes in villages, peaceful environment and functioning of the panchayat. The equation for PO logistic regression can be given as follows:

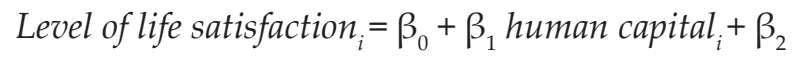
material capital $+\beta_{3}$ social capital $_{i}+\varepsilon_{i}$

Where there are $N$ individuals, indexed $i=1 \ldots N$ such that;

(a) The variable on the left-hand side (L.H.S) level of life satisfaction is ordinal of three categories and taken as regressand.

(b) The variables on the right-hand side (R.H.S.) are the regressors of the model and are the error term and residuals.

The PO model for these three different capitals has been fitted as Model 1 including only human capital, Model 2 including both human and material capital, and Model 3 including all three types of capital e.g. human, material and social.

The Brant test was then used as the analysis of the post-estimation test to examine the $\mathrm{PO}$ assumption (parallel line assumption) and identify regressors that violated the assumption. After that, based on Brant test diagnostic the study uses the generalised ordinal logit model or PPO model to correctly specify our model of estimation of life satisfaction level on the same equation one (equation 6). Although the PPO model allows the effects of all regressors to vary even when some violate the $\mathrm{PO}$ assumption, it can put equal-slope constraints on those regressors whose effects are constant across cut points (Liu \& Koirala 2012).

\section{RESULTS AND ANALYSIS}

For the year 2013-14 outcome variable; life satisfaction level, which is an ordinal variable with three levels (low, medium, and high) showed the hierarchical structure as category high indicates higher levels of all previous levels.
Table 2 provides the categories and frequencies of all satisfaction levels. The sample frequency distribution shows all three categories are having approximately equal weight and more than two-thirds of the sample fall in the low or medium life satisfaction category.

Table 2: Life satisfaction categories and proportions for sample SQUAT 2013-14

\begin{tabular}{lll}
\hline $\begin{array}{l}\text { Life satisfaction } \\
\text { categories }\end{array}$ & Description & Frequencies \\
\hline Low & $\begin{array}{l}\text { Life satisfaction } \\
\text { ladder scores from }\end{array}$ & $7133(29.82)$ \\
& 1 to 4 & \\
& Life satisfaction & $8388(35.07)$ \\
ladder scores from & \\
& 5 to 8 & \\
& $\begin{array}{l}\text { Life satisfaction } \\
\text { ladder scores from } 9\end{array}$ & \\
and above & \\
\hline
\end{tabular}

Source: SQUAT 2013-14 and figures in parentheses are proportions in the column.

A PO model for human capital was fitted first (Model 1) and subsequently, the models for material (Model 2) and social capital (Model 3) were estimated. The overall model fit for Model 1, = 3739.97, $\mathrm{p}<0.01$, indicates that the coefficient of the regressors was statistically significantly different from 0 (see table 3 ). The estimated logit regression coefficient for human capital indicated that all three variables e.g. age, level of education, and health status is taken as human capital indicators, had a positive and significant effect on life satisfaction level for rural north India. Particularly, the health of an individual is directly related to life satisfaction and better health leads to a more satisfying life, whereas age (experience) and education are less important than health in deciding life satisfaction but still significantly affecting one's perception about life satisfaction.

The odds $(>1)$ for human capital indicated that the likelihood of being at or below a particular level of satisfaction relative to beyond that level increases as a unit increase in human capital indicators. In other words, a higher level of human capital, particularly the health of an individual, was related to the likelihood of being in a higher level of life satisfaction. 
Determinants of Life Satisfaction for Rural North Indians: Estimation Using Generalised Ordinal Logistic Regression $\underset{\text { AESSRA }}{J_{S}}$

Model 2 which was fitted with human and material capital showed the model gets better with material capital and the log-likelihood ratio or Pseudo $R^{2}$ increases from 0.0970 to 0.1184 with the better overall model fit, $\chi^{2}=4563.55, \mathrm{p}<0.01$ (see table 3 ).

Table 3: Results of the proportional odds model (ordinal logistic regression)

\begin{tabular}{|c|c|c|c|c|c|c|}
\hline \multirow{2}{*}{ Variables } & \multicolumn{2}{|c|}{$\begin{array}{c}\text { Model 1 } \\
(\mathrm{N}=17606)\end{array}$} & \multicolumn{2}{|c|}{$\begin{array}{c}\text { Model } 2 \\
(\mathrm{~N}=17606)\end{array}$} & \multicolumn{2}{|c|}{$\begin{array}{c}\text { Model } 3 \\
(\mathrm{~N}=17091)\end{array}$} \\
\hline & B & $\begin{array}{l}\text { Odds } \\
\text { Ratio }\end{array}$ & B & $\begin{array}{l}\text { Odds } \\
\text { Ratio }\end{array}$ & B & $\begin{array}{l}\text { Odds } \\
\text { Ratio }\end{array}$ \\
\hline & 0.888 & & 2.062 & & 2.651 & \\
\hline & 2.708 & & 3.947 & & 4.551 & \\
\hline Age & $\begin{array}{l}0.002^{* *} \\
(0.0008)\end{array}$ & 1.002 & $\begin{array}{l}-0.001 \\
(0.0008)\end{array}$ & 0.999 & $\begin{array}{l}-0.001 \\
(0.0008)\end{array}$ & 0.999 \\
\hline Education & $\begin{array}{l}0.028^{* * *} \\
(0.0030)\end{array}$ & 1.028 & $\begin{array}{l}-0.001 \\
(0.0032)\end{array}$ & 0.999 & $\begin{array}{l}-0.002 \\
(0.0033)\end{array}$ & 0.998 \\
\hline Health & $\begin{array}{l}0.27^{* * *} \\
(0.0051)\end{array}$ & 1.312 & $\begin{array}{l}0.26^{* * *} \\
(0.0052)\end{array}$ & 1.292 & $\begin{array}{l}0.26^{* * *} \\
(0.0053)\end{array}$ & 1.289 \\
\hline Laborer & & & $\begin{array}{l}0.007 \\
(0.0433)\end{array}$ & 1.007 & $\begin{array}{l}0.006 \\
(0.0444)\end{array}$ & 1.006 \\
\hline $\begin{array}{l}\text { Self- } \\
\text { employed }\end{array}$ & & & $\begin{array}{l}0.41^{* * *} \\
(0.0472)\end{array}$ & 1.499 & $\begin{array}{l}0.41^{* * *} \\
(0.0482)\end{array}$ & 1.504 \\
\hline Salariat & & & $\begin{array}{l}0.31^{* * *} \\
(0.0503)\end{array}$ & 1.364 & $\begin{array}{l}0.29^{* * *} \\
(0.0510)\end{array}$ & 1.334 \\
\hline $\begin{array}{l}\text { Agricultural } \\
\text { land }\end{array}$ & & & $\begin{array}{l}0.35^{* * *} \\
(0.0410)\end{array}$ & 1.412 & $\begin{array}{l}0.33^{* * *} \\
(0.0421)\end{array}$ & 1.384 \\
\hline Asset count & & & $\begin{array}{l}0.09^{* * *} \\
(0.0040)\end{array}$ & 1.088 & $\begin{array}{l}0.08^{* * *} \\
(0.0042)\end{array}$ & 1.087 \\
\hline OBC & & & & & $\begin{array}{l}-0.19^{* * *} \\
(0.0365)\end{array}$ & 0.830 \\
\hline SC/ST & & & & & $\begin{array}{l}-0.11^{* *} \\
(0.0464)\end{array}$ & 0.899 \\
\hline $\begin{array}{l}\text { Heterogene- } \\
\text { ity of castes }\end{array}$ & & & & & $\begin{array}{l}0.12^{* * *} \\
(0.0438)\end{array}$ & 1.129 \\
\hline $\begin{array}{l}\text { Peaceful } \\
\text { environment }\end{array}$ & & & & & $\begin{array}{l}0.00005^{* *} \\
(0.0000)\end{array}$ & 1.00005 \\
\hline $\begin{array}{l}\text { Functioning } \\
\text { of Panchayat }\end{array}$ & & & & & $\begin{array}{l}0.31^{* * *} \\
(0.0266)\end{array}$ & 1.358 \\
\hline Male & $\begin{array}{l}-0.09^{* * *} \\
(0.0298)\end{array}$ & 0.911 & $\begin{array}{l}-0.02 \\
(0.0302)\end{array}$ & 0.981 & $\begin{array}{l}-0.02 \\
(0.0308)\end{array}$ & 0.984 \\
\hline
\end{tabular}

\begin{tabular}{lllllll} 
Bihar & $-0.62^{* * *}$ & 0.534 & $-0.17^{* * *}$ & 0.840 & -0.07 & 0.935 \\
& $(0.0457)$ & & $(0.0511)$ & & $(0.0529)$ & \\
U.P. & $-0.53^{* * *}$ & 0.583 & $-0.10^{*}$ & 0.907 & 0.03 & 1.028 \\
& $(0.0459)$ & & $(0.0514)$ & $(0.0529)$ & \\
M.P. & $-0.10^{* *}$ & 0.909 & $0.33^{* * *}$ & 1.395 & $0.41^{* * *}$ & 1.507 \\
& $(0.0455)$ & & $(0.0504)$ & $(0.0514)$ & \\
Rajasthan & $0.11^{* *}$ & 1.120 & $0.35^{* * *}$ & 1.420 & $0.40^{* * *}$ & 1.493 \\
& $(0.0551)$ & $(0.0584)$ & $(0.0611)$ & \\
\hline LR R & 0.0970 & 0.1184 & 0.1234 & \\
\hline Brant test & $\chi_{8}^{2}=131.4^{* * *}$ & $\chi_{13}{ }^{2}=347.0^{* * *}$ & $\chi_{18}{ }^{2}=426.0^{* * *}$ \\
\hline Model fit & $\chi_{1}^{2}=3739.97^{* * *}$ & $\chi_{2}{ }^{2}=4563.55^{* * *}$ & $\chi_{3}{ }^{2}=4619.05^{* * *}$ \\
\hline
\end{tabular}

Source: Computed from SQUAT data.

Note: Standard errors are in parentheses, $N$ stands for sample size and ${ }^{*} p<0.10,{ }^{* *} p<0.05,{ }^{* * *} p<0.01$.

After including the variables for material capital e.g. labour market status, possession of agricultural land, and asset count, human capital variables like; age and education became insignificant but still, the variable of health status was significantly affecting life satisfaction level which again proves the importance of better health in deciding life satisfaction for rural north Indians. The logit regression coefficients for material capital showed that better employment or labour market status, possession of agricultural land, and increased asset count was related to the likelihood of being at a higher level of life satisfaction. It is evident from the regression coefficients and odds of material capital that it is positively significantly related to life satisfaction level, particularly being in self-employment and possession of agricultural land in rural north India was highly significant and positively related to an increased likelihood of being in the higher level of life satisfaction.

Our full PO Model (model 3) that is for human, material, and social capital has a better fit and the loglikelihood ratio or Pseudo $R^{2}$ increases from 0.1184 to 0.1234 (see table 3). Logit coefficients and odds for social capital variables e.g. heterogeneity of castes, peaceful environment, and functioning of panchayats in villages were significantly positively associated with the level of life satisfaction and social identity or being associated with a particular caste or social category was significantly associated with life satisfaction level in rural north India. Being an individual from the OBC and SC/ST community was associated with lower levels 
$\underset{\text { AESSRA }}{\mathscr{L}_{\mathcal{L}}}$ Sharma

of satisfaction when compared to the general caste. This showed caste norms are still prevalent at least in rural north India setup and life satisfaction is merely not associated with socio-economic and demographic variables. Individual life satisfaction also depends on good governance, social harmony, and the caste identity of an individual.

The full model also estimated five cut points, which were used to differentiate among adjoining categories of level of life satisfaction. Here and were the cut points for a logistic model for $Y>1$ and $Y>2$ respectively.

Table 4: Brant tests of the proportional odds (PO) assumption for each predictor and the overall model

\begin{tabular}{lll}
\hline Variable & Chi-squared test statistic & p-value \\
\hline Age & 0.03 & 0.860 \\
Education & 2.91 & $0.088^{*}$ \\
Health & 6.63 & $0.010^{* * *}$ \\
Main occupation & 0.37 & 0.546 \\
Agricultural land & 18.75 & $0.000^{* * *}$ \\
Asset count & 183.25 & $0.000^{* * *}$ \\
Social category & 0.54 & 0.462 \\
Heterogeneity of & 0.37 & 0.542 \\
castes & & \\
Peaceful & 33.20 & $0.000^{* * *}$ \\
environment & & \\
Functioning of & 15.14 & $0.000^{* * *}$ \\
Panchayat & & \\
Male & 2.61 & 0.106 \\
State dummies & 9.11 & $0.003^{* * *}$ \\
All (overall model) & $370.47(12)$ & $0.000^{* * *}$ \\
\hline
\end{tabular}

Source: Computed from SQUAT data.

Note: Degree of freedoms are in parentheses and ${ }^{*} p<0.10,{ }^{* *} p<0.05$, *** $p<0.01$.

The Brant test is used to identify whether the overall model/separate variables (each predictor) follow the PO assumption or not. Table 4 presents the respective chi-square test statistics and corresponding $\mathrm{p}$ values for each predictor variable. The Brant test for the overall model, $\chi_{12}{ }^{2}=370.47, \mathrm{p}=0.000$, points out that the $\mathrm{PO}$ assumption for the overall model gets violated (see table 4). A separate Brant test for each predictor shows that the Brant test was violated for predictors like; the level of education, health, possession of the agricultural land, asset count, peaceful environment, and proper functioning of Panchayats in villages. Violation of the PO assumption leads to the use of the Partial Proportional Odds (PPO) model because of the limitation related to the earlier model (e.g. PO model). The PPO or generalised ordinal logit model relaxes the proportionality assumption by allowing the logit effects of predictor variables to vary across cut points which dichotomise the underlying outcome variable e.g. life satisfaction (e.g. $Y>1$ vs. $Y \leq 1$ and $Y>2$ vs. $Y \leq 2$ ).

The generalised ordinal model estimates the logistic coefficients and corresponding odds ratios for all regressors at different levels/categories e.g. beyond one level versus at or below that level. The outcome variable (e.g. life satisfaction level) has three categories so in the PPO model, I have two categories to be compared. After relaxing the $\mathrm{PO}$ assumption, the model fit gets better and LR $R^{2}$ increased up to 0.1328 from 0.1234 for the full PPO model (see table 5).

Table 5: Results of Partial Proportional Odds Model (Generalised Ordinal Logit)

\begin{tabular}{|c|c|c|c|c|}
\hline \multirow[b]{2}{*}{ Variables } & \multicolumn{2}{|c|}{$Y>1$ vs. $Y \leq 1$} & \multicolumn{2}{|c|}{$Y>2$ vs. $Y \leq 2$} \\
\hline & B & $\begin{array}{l}\text { Odds } \\
\text { Ratio }\end{array}$ & B & $\begin{array}{l}\text { Odds } \\
\text { Ratio }\end{array}$ \\
\hline Age & $\begin{array}{l}-0.001 \\
(0.0008411)\end{array}$ & 0.999 & $\begin{array}{l}-0.001 \\
(0.0008411)\end{array}$ & 0.999 \\
\hline Education & $\begin{array}{l}-0.007 \\
(0.0042625)\end{array}$ & 0.993 & $\begin{array}{l}0.0002 \\
(0.0038356)\end{array}$ & 1.0002 \\
\hline Health & $\begin{array}{l}0.245^{* * *} \\
(0.0063679)\end{array}$ & 1.276 & $\begin{array}{l}0.266^{* * *} \\
(0.0069679)\end{array}$ & 1.305 \\
\hline Laborer & $\begin{array}{l}0.045 \\
(0.0443707)\end{array}$ & 1.046 & $\begin{array}{l}0.045 \\
(0.0443707)\end{array}$ & 1.046 \\
\hline Self-employed & $\begin{array}{l}0.408^{* * *} \\
(0.0484851)\end{array}$ & 1.504 & $\begin{array}{l}0.408^{* * *} \\
(0.0484851)\end{array}$ & 1.504 \\
\hline Salariat & $\begin{array}{l}0.302^{* * *} \\
(0.0515509)\end{array}$ & 1.352 & $\begin{array}{l}0.302^{* * *} \\
(0.0515509)\end{array}$ & 1.352 \\
\hline $\begin{array}{l}\text { Agricultural } \\
\text { land }\end{array}$ & $\begin{array}{l}0.426^{* * *} \\
(0.047257)\end{array}$ & 1.530 & $\begin{array}{l}0.202^{* * *} \\
(0.0486168)\end{array}$ & 1.224 \\
\hline Asset count & $\begin{array}{l}0.133^{* * *} \\
(0.0054738)\end{array}$ & 1.142 & $\begin{array}{l}0.057^{* * *} \\
(0.0046065)\end{array}$ & 1.059 \\
\hline OBC & $\begin{array}{l}-0.190^{* * *} \\
(0.0368582)\end{array}$ & 0.827 & $\begin{array}{l}-0.190^{* * *} \\
(0.0368582)\end{array}$ & 0.827 \\
\hline SC/ST & $\begin{array}{l}-0.103^{* *} \\
(0.046473)\end{array}$ & 0.902 & $\begin{array}{l}-0.103^{* *} \\
(0.046473)\end{array}$ & 0.902 \\
\hline
\end{tabular}




\begin{tabular}{|c|c|c|c|c|}
\hline $\begin{array}{l}\text { Heterogeneity } \\
\text { of castes }\end{array}$ & $\begin{array}{l}0.131^{* * *} \\
(0.0441156)\end{array}$ & 1.140 & $\begin{array}{l}0.131^{* * *} \\
(0.0441156)\end{array}$ & 1.140 \\
\hline $\begin{array}{l}\text { Peaceful } \\
\text { environment }\end{array}$ & $\begin{array}{l}-0.00002 \\
(0.0000215)\end{array}$ & 0.999 & $\begin{array}{l}0.00009^{* * *} \\
(0.0000194)\end{array}$ & 1.00009 \\
\hline $\begin{array}{l}\text { Functioning of } \\
\text { Panchayat }\end{array}$ & $\begin{array}{l}0.374^{* * *} \\
(0.033005)\end{array}$ & 1.453 & $\begin{array}{l}0.239^{* * *} \\
(0.03136)\end{array}$ & 1.271 \\
\hline Male & $\begin{array}{l}-0.015 \\
(0.0309292)\end{array}$ & 0.985 & $\begin{array}{l}-0.015 \\
(0.0309292)\end{array}$ & 0.985 \\
\hline Bihar & $\begin{array}{l}-0.047 \\
(0.0534339)\end{array}$ & 0.954 & $\begin{array}{l}-0.047 \\
(0.0534339)\end{array}$ & 0.954 \\
\hline U.P. & $\begin{array}{l}0.033 \\
(0.0535006)\end{array}$ & 1.033 & $\begin{array}{l}0.033 \\
(0.0535006)\end{array}$ & 1.033 \\
\hline M.P. & $\begin{array}{l}0.407^{* * *} \\
(0.0519682)\end{array}$ & 1.503 & $\begin{array}{l}0.407^{* * *} \\
(0.0519682)\end{array}$ & 1.503 \\
\hline Rajasthan & $\begin{array}{l}0.415^{* * *} \\
(0.0617508)\end{array}$ & 1.514 & $\begin{array}{l}0.415^{* * *} \\
(0.0617508)\end{array}$ & 1.514 \\
\hline & $\begin{array}{l}\alpha_{1}=-3.168^{* * *} \\
(0.1400404)\end{array}$ & & $\begin{array}{l}\alpha_{2}=-4.215^{* * *} \\
(0.1455771)\end{array}$ & \\
\hline $\mathrm{LR}^{2}$ & \multicolumn{4}{|c|}{$0.1328(\mathrm{~N}=17091)$} \\
\hline Model fit & \multicolumn{4}{|c|}{$\chi_{24}^{2}=4971.24^{* * *}$} \\
\hline
\end{tabular}

Source: Computed from SQUAT data.

Note: Standard errors are in parentheses, $N$ stands for sample size and ${ }^{*} p<0.10,{ }^{* *} p<0.05,{ }^{* * *} p<0.01$.

Table 5 indicates that for predictors like; the level of education, health, possession of the agricultural land, asset count, peaceful environment, and proper functioning of Panchayats in villages the odds ratios are different for different comparable categories because for these predictors the $\mathrm{PO}$ assumption was violated and for rest of the predictors the odds are same in different categories. Better human capital like the increased level of education and better health except for the age of an individual was associated with the likelihood of being in a higher life satisfaction level. The effect of increased education was first negative and further became positive with lower to a higher level of life satisfaction although better health was positively affecting in an increased level of life satisfaction and the effect became stronger when satisfaction level moved from low/middle to high.

The effects of material capital like possession of agricultural land and asset count were also positively associated with the likelihood of being above a particular level of life satisfaction as opposed to being at or below that level. It is clear from the odds that the effects of material capital became weaker when life satisfaction level moved from low to high. Among social capital the effect of a peaceful environment of the village was first negative and further became positive with lower to a higher level of life satisfaction, moreover; better functioning of Panchayats in villages was associated with the likelihood of being in a higher level of life satisfaction and the effect became much stronger when satisfaction level moved from low to high.

\section{CONCLUSION, POLICY IMPLICATIONS, AND LIMITATIONS}

To analyse the determinants of life satisfaction level for rural north Indians, the study estimated first, proportional odds logistic regression, followed by generalised ordinal logistic regression techniques. It is evident from the analysis that the overall $\mathrm{PO}$ assumption, as well as separate PO assumptions for most of the variables, is violated and, in that case, generalised ordinal logistic regression may provide a better model. From the analysis, it is very clear that for rural north Indians the level of life satisfaction is most affected by health status, possession of agricultural land, and administrative environment of villages (e.g. functioning of Panchayats). Better health, possession of agricultural land, and better functioning of Panchayats significantly affect the life satisfaction level of rural north Indians after controlling for gender and regional differences. The effects of other capitals like better occupation, increased assets, heterogeneity of castes, and peaceful environment are also significant except age and education of an individual in rural north India. Our results got support from previous studies like Banjare et al. (2015), Jagodzinski (2010), Ngoo et al. (2015), and Spears (2016) who explored the same social, cultural, and caste norms prevalent in deciding one's well-being or satisfaction from life.

The results indicate policy implications in advancing health facilities in rural India. This is only a part of good governance and the overall functioning of local governance can be made more transparent which was most significant in deciding life satisfaction because individuals or society expect so much from an elected government in a democracy. Besides, agricultural land being a resource in rural India affects life satisfaction 
very significantly. Particularly for those who do not possess agricultural land and mainly for the socially deprived sections of society, the policy of land reforms is most important. Why education is not significant in deciding life satisfaction for rural north Indians can be interpreted as very low educational outcome and occupational opportunities in rural India. The implications may be limiting as the sample consists of only five states from rural India and I may get more precise estimations using a larger sample size consisting of all the rural settlements of India. This also helps to get some potential directions for future studies to have a larger sample size and include some other psychological aspects relating to life satisfaction which may be done with an interdisciplinary approach.

\section{ACKNOWLEDGMENTS}

The views expressed in this paper are those of the author and do not reflect the views of the institution to which the author is affiliated. I thank my colleagues who provided insights and expertise which greatly assisted the research, although any errors are my own and should not tarnish the reputation of esteemed persons from respective institutions.

\section{REFERENCES}

Alexandrova, A. 2005. 'Subjective well-being and Kahneman's "objective happiness", Journal of Happiness Studies, 6(3): 301324.

Angelini, V., Bertoni, M. and Corazzini, L. 2017. 'Unpacking the determinants of life satisfaction: a survey experiment', Journal of the Royal Statistical Society, 180(1): 225-246.

Anheier, H.K., Stares, S. and Grenier, P. 2004. 'Social Capital and Life Satisfaction'. In W.A. Arts \& L. Halman (Eds.), European Values at the Turn of the Millennium (pp. 81-108). Boston: Brill Academic Publishers, Inc.

Antaramian, S., Kamble, S.V. and Scott Huebner, E. 2015. 'Life Satisfaction and Coping in Hindu Adolescents in India', Journal of Happiness Studies, 17(4).

Banjare, P., Dwivedi, R. and Pradhan, J. 2015. 'Factors associated with the life satisfaction amongst the rural elderly in Odisha, India', Health and Quality of Life Outcomes, 13(201).

Bjornscov, C. 2005. 'The Multiple Facets of Social Capital', European Journal of Political Economy, 22(1): 22-40.

Borg, C., Hallberg, I. and Blomqvist, K. 2006. 'Life satisfaction among older people (65+) with reduced self-care capacity: the relationship to social, health and financial aspects', Journal of Clinical Nursing, 15(5): 607-618.

Coffey, D., Gupta, A., Hathi, P., Khurana, N., Spears, D., Srivastav, N. and Vyas, S. 2014. 'Revealed preference for open defecation: Evidence from new survey data', Economic and Political Weekly, 49(38).

Deaton, A. and Stone, A. 2013. 'Two Happiness Puzzles', American Economic Review, 103(3): 591-597.

Diener, E., Emmons, R., Larsen, R. and Griffin, S. 1985. 'The Satisfaction with Life Scale', Journal of Personality Assessment, 49(1): 71-75.

Diener, E. and Seligman, M.E.P. 2004. ‘Beyond Money: Toward an Economy of Well-Being', Psychological Science in the Public Interest, 5(1): 1-31.

Dolan, P., Peasgood, T. and White, M. 2008. 'Do we really know what makes us happy? A review of the economic literature on the factors associated with subjective well-being', Journal of Economic Psychology, 29(1): 94-122.

Ebrahim, A., Botha, F. and Snowball, J. 2013. 'Determinants of life satisfaction among race groups in South Africa', Development Southern Africa, 30(2): 168-185.

Frey, B.S. and Stutzer, A. 2006. 'Mispredicting Utility and the Political Process'. In E.J. McCaffery and J. Slemrod (Eds.). Behavioral Public Finance (pp. 113-140). New York: Russell Sage Foundation.

Hayo, B. 2004. Happiness in Eastern Europe (Working Paper 12/2004), Marburg: Phillips Universität Marburg. Retrieved from http://econwpa.repec.org/eps/pe/papers/0410/0410002. pdf

Helliwell, J.F. and Putnam, R.D. 2004. 'The Social Context of WellBeing'. In F.A. Huppert, N. Baylis and B. Kaverne, (Eds.). The Science of Well-Being (pp. 1435-1446 reprinted). London: Oxford University Press, 2005.

Jagodzinski, W. 2010. 'Economic, Social, and Cultural Determinants of Life Satisfaction: Are there Differences Between Asia and Europe?'. Social Indicators Research, 97(1): 85-104.

Kawachi, I., Subramanian, S. and Kim, D. 2008. 'Social Capital and Health', In I. Kawachi, S. Subramanian, D. Kim (Eds.). Social Capital and Health (pp. 1-26). Springer, New York, NY. DOI: https://doi.org/10.1007/978-0-387-71311-3_1

Li, D., Xu, X., Qin, X. and Guo, R. 2012. 'Study on Score of Happiness among the Elderly Population in Aged Apartment House in Tangshan'. International Conference on Education Technology and Management Engineering. Lecture Notes in Information Technology, 16-17, 432-436. Retrieved fromhttp://cstm.cnki.net/stmt/TitleBrowse/KnowledgeNet/ XXGC201206001093?db=STMI8515 
Liu, X. and Kiorala, H. 2013. 'Fitting Proportional Odds Models to Educational Data with Complex Sampling Designs in Ordinal Logistic Regression', Journal of Modern Applied Statistical Methods, 12(1): 235-248.

Maassa, R., Kloecknerc, C.A., Lindstromd, B. and Lillefjella, M. 2016. 'The impact of neighborhood social capital on life satisfaction and self-rated health: A possible pathway for health promotion?', Health E Place, 42: 120-128.

Myers, D.G. and Diener, E. 1995. 'Who is happy?', Psychological Science, 6(1): 10-19.

Neugarten, B., Havighurst, R. and Tobin, S. 1961. 'The Measurement of Life Satisfaction', Journal of Gerontology, 16: 134-143.

Ngoo, Y.T., Tey, N.P. and Tan, E.C. 2015. 'Determinants of Life Satisfaction in Asia', Social Indicators Research, 124(1): 141-156.

Sen, A. 1990. 'On Ethics and Economics'[e-book]. Retrieved from https://books.google.co.in/books?id=NYSnPwAACAAJ

Spears, D. 2016. 'Caste and life satisfaction in rural North India', Economic and Political Weekly, 51(4): 12-14.

Takahashi, K., Thuy, N.T.M., Poudel, K.C., Sakisaka, K., Jimba M. and Yasuoka, J. 2011. 'Social capital and life satisfaction: A cross-sectional study on persons with musculoskeletal impairments in Hanoi, Vietnam', BMC Public Health, 11(206).
Veenhoven, R. 1996. 'The study of life satisfaction'. In W. Saris, R. Veenhoven, A. Scherpenzeel, B. Bunting (Eds.). A comparative study of satisfaction with life in Europe (pp. 11-48). Budapest, Hungary: Eötvös University Press. Retrieved from https:// personal.eur.nl/veenhoven/Pub1990s/96c-ch1-full.pdf

World Health Organisation. 2003. 'Social determinants of health: the solid facts ( $2^{\text {nd }}$ Ed.)Copenhagen: WHO Regional Office for Europe'. Retrieved from http://www.euro.who.int/_data/ assets/pdf_file/0005/98438/e81384.pdf

Zaidi, S., Alam, A., Mitra, P. and Sundaram, R. 2009. 'Satisfaction with life and service delivery in Eastern Europe and the former Soviet Union: Some insights from the 2006 life in transition survey' (World Bank working paper no. 162). Washington D.C.: The World Bank. Retrieved from https://openknowledge.worldbank.org/bitstream/handle/ 10986/5955/476120PUB0Russ101Official0Use0Only1. pdf? sequence $=1$ \&isAllowed $=y$. 
